\title{
Transcriptome profile of OVCAR3 cisplatin-resistant ovarian cancer cell line
}

\author{
Shruti S Sakhare ${ }^{1 \dagger}$, Gautam G Rao ${ }^{2+}$, Sammed N Mandape ${ }^{1}$, Siddharth Pratap ${ }^{1 *}$ \\ From UT-KBRIN Bioinformatics Summit 2014 \\ Cadiz, KY, USA. 11-13 April 2014
}

\section{Background}

The NIH:OVCAR-3 is a cisplatin refractory cell line established from malignant ascites of a patient with progressive adenocarcinoma of the ovary after combination chemotherapy with cyclophosphamide, Adriamycin, and cisplatin [1]. Thus, OVCAR3 serves as a model cell line for drug resistance in ovarian cancer. Here, we perform a comparative transcriptome analysis from the US National Cancer Institute human tumor cell line anticancer drug screen (NCI60) dataset [2]. Our results indicate a specific gene transcription profile of OVCAR3 genes relative to non-cancerous Human Ovarian Surface Epithelial cells (HOSE) and drug sensitive Serous Ovarian Cancer Epithelial Samples (CEPI) and SKOV3 cell lines. Pathway enrichment analysis from OVCAR3 unique transcripts was conducted using KEGG; Disease and Drug term enrichment used the PharmGKB [3] databases.

\section{Materials and methods}

Datasets from the NCI60 were obtained from the Gene Expression Omnibus (GEO) of NCBI [4] (OVCAR3 and SKOV3 from series GSE2003, OSE and CEPI from series

Table 1 Transcripts differentially expressed in OVCAR3 versus SKOV3 and CEPI having significant enrichment scores in KEGG Pathway, PharmGKB Drug and Disease databases.

\begin{tabular}{|c|c|c|}
\hline $\begin{array}{l}\text { Gene } \\
\text { Symbol }\end{array}$ & Gene Name & Ensembl \\
\hline $\mathrm{ABCC} 4$ & ATP-binding cassette, sub-family C (CFTR/MRP), member 4 & ENSG00000125257 \\
\hline AKR1C2 & $\begin{array}{l}\text { aldo-keto reductase family } 1 \text {, member } \mathrm{C2} \text { (dihydrodiol dehydrogenase 2; bile acid binding protein; 3-alpha } \\
\text { hydroxysteroid dehydrogenase, type III) }\end{array}$ & ENSG00000151632 \\
\hline MLH1 & mutL homolog 1, colon cancer, nonpolyposis type 2 (E. coli) & ENSG00000076242 \\
\hline GLS & glutaminase & ENSG00000115419 \\
\hline ITGA3 & integrin, alpha 3 (antigen CD49C, alpha 3 subunit of VLA-3 receptor) & ENSG00000005884 \\
\hline UGT1A6 & UDP glucuronosyltransferase 1 family, polypeptide A6 & ENSG00000167165 \\
\hline PPARG & peroxisome proliferator-activated receptor gamma & ENSG00000132170 \\
\hline NNMT & nicotinamide $\mathrm{N}$-methyltransferase & ENSG00000166741 \\
\hline PTGIS & prostaglandin 12 (prostacyclin) synthase & ENSG00000124212 \\
\hline $\mathrm{ABCC} 3$ & ATP-binding cassette, sub-family C (CFTR/MRP), member 3 & ENSG00000108846 \\
\hline UGT1A1 & UDP glucuronosyltransferase 1 family, polypeptide A1 & ENSG00000241635 \\
\hline ERBB2 & v-erb-b2 erythroblastic leukemia viral oncogene homolog 2, neuro/glioblastoma derived oncogene homolog (avian) & ENSG00000141736 \\
\hline AKR1C1 & $\begin{array}{c}\text { aldo-keto reductase family } 1 \text {, member C1 (dihydrodiol dehydrogenase 1; 20-alpha (3-alpha)-hydroxysteroid } \\
\text { dehydrogenase) }\end{array}$ & ENSG00000187134 \\
\hline FGF2 & fibroblast growth factor 2 (basic) & ENSG00000138685 \\
\hline
\end{tabular}

\footnotetext{
* Correspondence: spratap@mmc.edu

† Contributed equally

${ }^{1}$ Bioinformatics Core, Meharry Medical College, Nashville, TN, 37208, USA

Full list of author information is available at the end of the article
} 


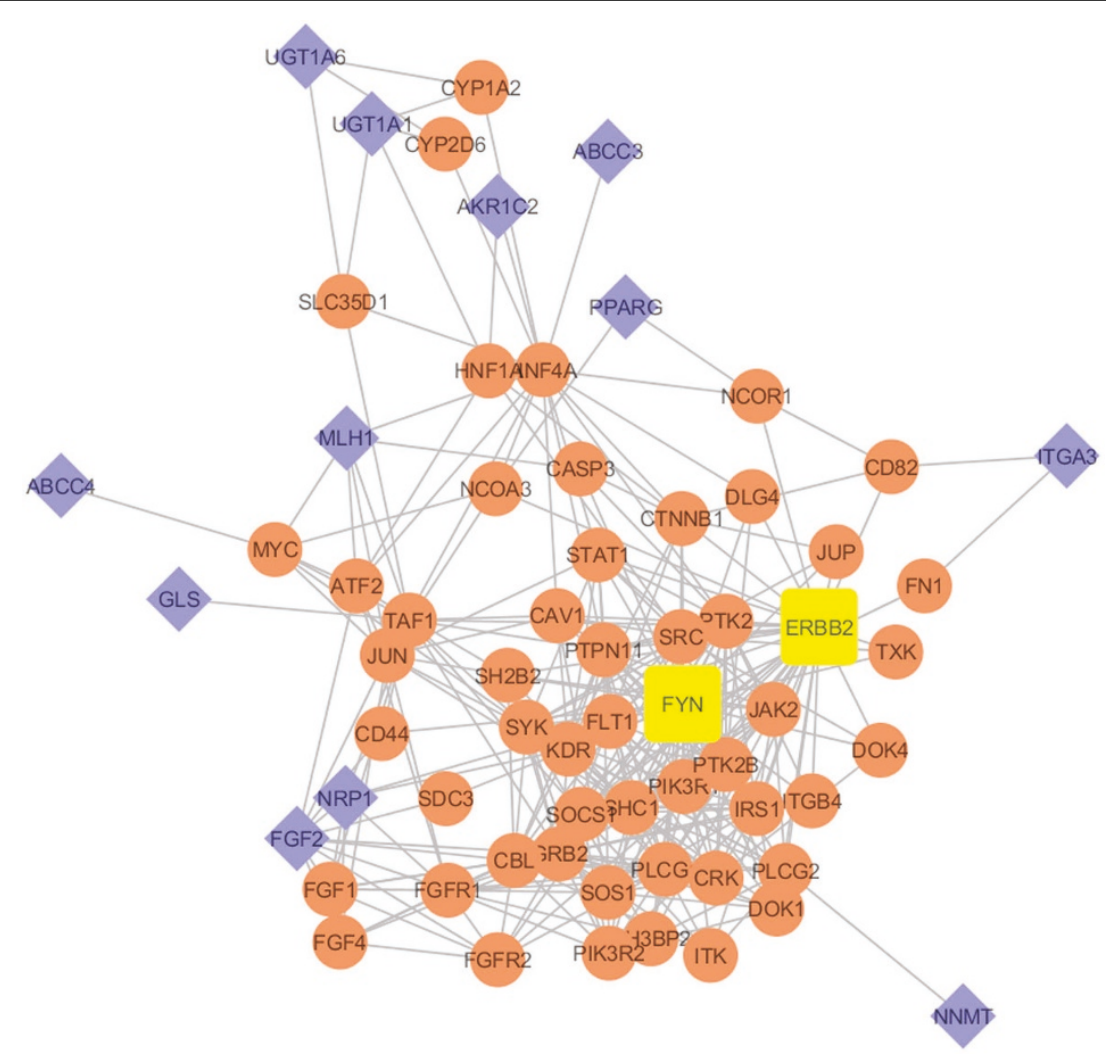

Figure 1 Interaction network of OVCAR3 unique genes. Diamond and rectangle nodes are seed nodes of 14 OVCAR3 unique genes; circular nodes are 1 degree of biological interactions; rounded rectangular nodes are the highly connected hubs in the network (FYN and ERBB2).

GDS3592 and GSE14407). Transcriptome data analysis was conducted with Partek Genomics Suite version 6.6. The WEB-based GEne SeT AnaLysis Toolkit (WebGestalt) was used to perform enrichment analysis [5]. Genes present in KEGG pathway, PharmGKB Disease, and Drug terms enrichment sets were connected and expanded to one degree of biological interaction using the Michigan Molecular Interactions databases plugin [6] and visualized using Cytoscape version 2.8.3 [7].

\section{Results}

Transcriptome analysis of OVCAR3 specific gene expression changes resulted in 160 significant transcripts with a fold change $> \pm 2$ and an ANOVA derived Benjamini Hochberg adjusted p-value $<0.001$. Enrichment analysis using a Hypergeometric test identified 189 PharmGKB Disease terms, 90 Drug terms and 31 KEGG pathways associated with these genes. A union of the disease, drug and KEGG pathway gene lists yielded 14 common genes for the dataset which were unique to OVCAR3 cells versus SKOV3 and CEPI (Table 1).

\section{Conclusions}

This list of OVCAR3 unique genes, and the resulting interactions graph (Figure 1) represent potential pathways of drug resistance associated genes in ovarian cancer. Notably, ERBB2 (HER2) and FYN are the hub genes of the interaction network specific for OVCAR3 cell line. Thus, they may provide valuable insights into the drug resistance etiology of ovarian cancer. ERBB2 (HER2) has previously been reported to interact with Estrogen Receptor (ESR2) in Breast Cancer [8] and FYN has been implicated in Glioblastoma and T-cell Lymphomas [9,10]; however their detailed roles in Ovarian Cancer have only recently been studied, warranting further investigation $[11,12]$.

\section{Acknowledgements}

Funding provided by NIH grants MD007586 and MD007593 from the National Institute on Minority Health and Health Disparities (NIMHD).

\section{Authors' details}

${ }^{1}$ Bioinformatics Core, Meharry Medical College, Nashville, TN, 37208, USA. ${ }^{2}$ Obstetrics, Gynecology and Reproductive Sciences, University of Maryland, Baltimore, MD, 21201, USA. 


\section{References}

1. Hamilton TC, Young RC, McKoy WM, Grotzinger KR, Green JA, Chu EW, Whang-Peng J, Rogan AM, Green WR, Ozols RF: Characterization of a human ovarian carcinoma cell line (NIH: OVCAR-3) with androgen and estrogen receptors. Cancer Res 1983, 43(11):5379-5389.

2. Shoemaker RH: The NCl60 human tumour cell line anticancer drug screen. Nat Rev Cancer 2006, 6(10):813-823.

3. Whirl-Carrillo M, McDonagh E, Hebert J, Gong L, Sangkuhl K, Thorn C, Altman R, Klein TE: Pharmacogenomics knowledge for personalized medicine. Clin PharmTher 2012, 92(4):414-417.

4. Gene Expression Omnibus. [http://www.ncbi.n/m.nih.gov/geo/]

5. Wang J, Duncan D, Shi Z, Zhang B: WEB-based GEne SeT AnaLysis Toolkit (WebGestalt): update 2013. Nucleic Acids Res 2013, 41(W1):W77-W83.

6. Tarcea VG, Weymouth T, Ade A, Bookvich A, Gao J, Mahavisno V, Wright Z, Chapman A, Jayapandian M, Özgür A: Michigan molecular interactions r2: from interacting proteins to pathways. Nucleic Acids Res 2009, 37(suppl 1): D642-D646.

7. Shannon P, Markiel A, Ozier O, Baliga NS, Wang JT, Ramage D, Amin N, Schwikowski B, Ideker T: Cytoscape: a software environment for integrated models of biomolecular interaction networks. Genome Res 2003, 13(11):2498-2504

8. Shou J, Massarweh S, Osborne CK, Wakeling AE, Ali S, Weiss H, Schiff R: Mechanisms of tamoxifen resistance: increased estrogen receptor-HER2/ neu cross-talk in ER/HER2-positive breast cancer. J Nat Cancer Inst 2004, 96(12):926-935.

9. Lu KV, Zhu S, Cvrljevic A, Huang TT, Sarkaria S, Ahkavan D, Dang J, Dinca EB, Plaisier SB, Oderberg I: Fyn and SRC are effectors of oncogenic epidermal growth factor receptor signaling in glioblastoma patients. Cancer Res 2009, 69(17):6889-6898.

10. Palomero T, Couronné L, Khiabanian H, Kim M-Y, Ambesi-Impiombato A, Perez-Garcia A, Carpenter Z, Abate F, Allegretta M, Haydu JE: Recurrent mutations in epigenetic regulators, RHOA and FYN kinase in peripheral T cell lymphomas. Nat Genet 2014, 46(2):166-170.

11. Le X-F, Mao W, He G, Claret F-X, Xia W, Ahmed AA, Hung M-C, Siddik ZH, Bast RC: The role of p27Kip1 in dasatinib-enhanced paclitaxel cytotoxicity in human ovarian cancer cells. J Nat Cancer Inst 2011, 103(18):1403-1422.

12. Vaughan S, Coward JI, Bast RC, Berchuck A, Berek JS, Brenton JD, Coukos G, Crum CC, Drapkin R, Etemadmoghadam D: Rethinking ovarian cancer: recommendations for improving outcomes. Nat Rev Cancer 2011, 11(10):719-725.

doi:10.1186/1471-2105-15-S10-P21

Cite this article as: Sakhare et al.: Transcriptome profile of OVCAR3 cisplatin-resistant ovarian cancer cell line. BMC Bioinformatics 2014 15(Suppl 10):P21.

\section{Submit your next manuscript to BioMed Central and take full advantage of:}

- Convenient online submission

- Thorough peer review

- No space constraints or color figure charges

- Immediate publication on acceptance

- Inclusion in PubMed, CAS, Scopus and Google Scholar

- Research which is freely available for redistribution

Submit your manuscript at www.biomedcentral.com/submit
C Biomed Central 